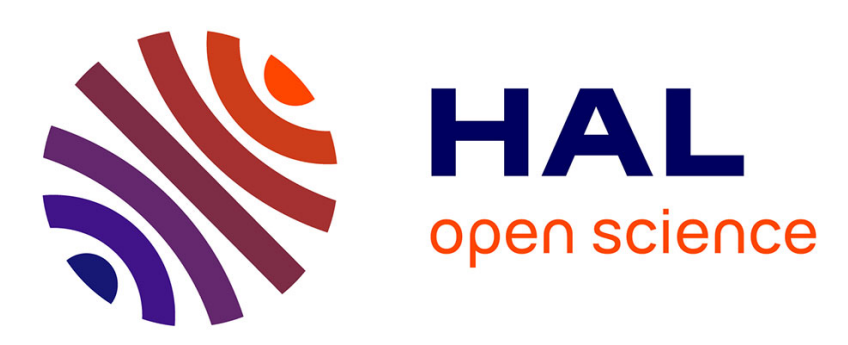

\title{
Ensemble effects of nickel in surfactant-less prepared Pt-Ni materials on the carbon monoxide oxidative removal
}

\author{
S. Dessources, C. Morais, C. Canaff, Teko Napporn, K. B Kokoh
}

\section{- To cite this version:}

S. Dessources, C. Morais, C. Canaff, Teko Napporn, K. B Kokoh. Ensemble effects of nickel in surfactant-less prepared Pt-Ni materials on the carbon monoxide oxidative removal. Journal of Solid State Electrochemistry, 2020, 25 (1), pp.219-223. 10.1007/s10008-020-04817-6 . hal-03055005

\author{
HAL Id: hal-03055005 \\ https://hal.science/hal-03055005
}

Submitted on 11 Dec 2020

HAL is a multi-disciplinary open access archive for the deposit and dissemination of scientific research documents, whether they are published or not. The documents may come from teaching and research institutions in France or abroad, or from public or private research centers.
L'archive ouverte pluridisciplinaire HAL, est destinée au dépôt et à la diffusion de documents scientifiques de niveau recherche, publiés ou non, émanant des établissements d'enseignement et de recherche français ou étrangers, des laboratoires publics ou privés. 


\title{
Ensemble Effects of Nickel in Surfactant-less Prepared Pt-Ni Materials on
}

\section{the Carbon Monoxide Oxidative Removal}

\author{
S. Dessources, C. Morais, C. Canaff, T. W. Napporn* and K. B. Kokoh ${ }^{\dagger}$ \\ Université de Poitiers, IC2MP-UMR CNRS 7285, 4 rue Michel Brunet B27, TSA 51106, 86073 Poitiers Cedex \\ 09, France.
}

\begin{abstract}
This work reports the effect of the $\mathrm{Ni}$ content in a $\mathrm{Pt}_{\mathrm{x}} \mathrm{Ni} / \mathrm{C}$ electrode on the $\mathrm{CO}$ oxidation reaction. A series of complementary and physicochemical techniques reveal the surface modification by the formation of Pt and Ni hydroxides which contribute to the removal of such model poisoning molecule in the utilization of organics as fuel in fuel cell applications. This cooperative activation of bimetallic materials, prepared without any organic surfactant, occurs at lower and lower potentials. As a result, a large $270 \mathrm{mV}$ cathodic shift is observed when increasing the $\mathrm{Ni}$ amount up to $80 \%$ in the $\mathrm{Pt}_{\mathrm{x}} \mathrm{Ni}_{\mathrm{y}}$ composition. XPS measurements are correlated with the electrochemical characterization of the $\mathrm{Pt}_{\mathrm{x}} \mathrm{Ni}_{\mathrm{y}} / \mathrm{C}$ electrodes surface through CO stripping investigations. Although there is a low shift of the $\mathrm{Pt} 4 \mathrm{f}_{7 / 2}$ peak, the presence of $\mathrm{Ni}-\mathrm{OH}$ species in the close environment of $\mathrm{Pt}-\mathrm{CO}_{\mathrm{ads}}$ mainly contributes to change the Langmuir-Hinshelwood mechanism into a bifunctional one which takes place at $c a .0 .40 \mathrm{~V}$ vs. RHE
\end{abstract}

Keywords: $\mathrm{Pt}_{\mathrm{x}} \mathrm{Ni}_{\mathrm{y}}$ electrocatalyst; CO-to- $\mathrm{CO}_{2}$ mechanisms; CO-stripping; $\mathrm{BAE}$ synthesis method

\footnotetext{
*Corresponding author: e-mail address: teko.napporn@univ-poitiers.fr (T.W. Napporn), https://orcid.org/0000-0003-1506-7139; Tel.: +33549453967

${ }^{\dagger}$ http://orcid.org/0000-0002-5379-7792 (K. B. Kokoh)

This paper is dedicated to Professor José H. Zagal on the occasion of his $70^{\text {th }}$ birthday and in recognition of his outstanding contribution to electrocatalysis.
} 


\section{Introduction}

In the Direct Alcohol Fuel Cells (DAFCs) investigations, carbon monoxide (CO) is pointed out as the main poisoning intermediate through its strong adsorption at the Pt-based electrode surface [1-4]. The development of such solid polymer electrolyte (SPE) systems involves the design of materials capable of releasing the electrode surface at lower potentials, which prolongs the durability of the catalytic process [5, 6]. Amongst the main alcohols commonly studied as promising fuels for sustainable applications such as SPE fuel cells, our research group contributed during these last decades to the possible development of DMFC (methanol) [7, 8], DEFC (ethanol) [9-11] and DGFC (glucose) [12, 13]. As can be evidenced through this literature, the breakthrough consists in adding a co-catalyst $(\mathrm{Sn}, \mathrm{Co}, \mathrm{Ru}, \mathrm{Ni}, \ldots)$ in the electrode composition to remove from the anodic surface at low potential values the remaining adsorbed $\mathrm{CO}$ formed during the alcohol oxidative conversion at the Pt-based material. This activity promoting element which is often a transition metal (TM) is considered to modify chemically, geometrically or electronically the properties of platinum. Consequently, the reaction can be controlled by the so-called bifunctional mechanism. If $\mathrm{Sn}$ and $\mathrm{Ru}$ were considered to contribute, respectively, to electronic and geometric effects in the enhancement of Pt electroactivity towards alcohol oxidation, $\mathrm{Ni}$ is a thermodynamically stable $\mathrm{TM}$ in alkaline medium and can play a co-catalyst role in the Pt-M anode towards alcohol oxidation. We synthesized by a surfactant-less method, e.g a bromide anion exchange approach, Pt-based catalysts for which the precious metal loading was "diluted" by adding various nickel amounts in order to investigate the effect towards the removal of $\mathrm{CO}$ from the electrode surface. This synergistic contribution of $\mathrm{Ni}$ observed by combining XPS and electrochemical methods (CO stripping/voltammetry) results in "ensemble effects" $[14,15]$, hard to discriminate and mainly 
composed of chemical (early formation of hydroxyl species at the electrode surface), electronic (shift in Pt4f) and geometric properties in the $\mathrm{Pt}_{\mathrm{x}} \mathrm{Ni}_{\mathrm{y}}$ electrode materials.

\section{Experimental}

The "Bromide Anion Exchange" (BAE) method, recently reported in ref. [16] was adapted to synthesize a large range of $\mathrm{Pt}_{\mathrm{x}} \mathrm{Ni}_{\mathrm{y}} / \mathrm{C}$ nanoparticles (x and y being the molar ratios of $\mathrm{Pt}$ and $\mathrm{Ni}$, respectively) [17]. The carbon substrate (Vulcan XC-72R, Cabot), used as matrix for preparing $\mathrm{Pt}_{\mathrm{x}} \mathrm{Ni}_{\mathrm{y}} / \mathrm{C}$ materials with $20 \mathrm{wt} . \%$. metal loading, was previously heat-treated at $400{ }^{\circ} \mathrm{C}$ under $\mathrm{N}_{2}$ atmosphere for $4 \mathrm{~h}$. XPS was also used to probe and characterize the surface and oxidation states of the obtained Pt-based materials. Analysis was performed in a high vacuum chamber on a Kratos Axis Ultra DLD spectrometer at pressure $\leq 910^{-8} \mathrm{~Pa}$, with a monochromatic radiation source $\left(\mathrm{Al}_{\mathrm{k} \alpha}: 1486.6 \mathrm{eV}\right)$ operating at $150 \mathrm{~W}(15 \mathrm{kV}$ and $10 \mathrm{~mA})$. Survey spectra were recorded with a step of $1 \mathrm{eV}$ (transition energy: $160 \mathrm{eV}$ ), which permits to check after the cleaning step whether the as-prepared materials do not contain any impurities (boron and bromide species from $\mathrm{NaBH}_{4}$ and $\mathrm{KBr}$ ). Based on the collected basic information, highresolution XPS spectra were collected at a step of $0.1 \mathrm{eV}$ (transition energy: $20 \mathrm{eV}$ ). XPS peaks were fitted using Gaussian-Lorentzian profile function and asymmetry determined from an etched bulk Pt metal. The cross-section Tougaard background has been chosen. It should be noted that a systematic subtraction of the background noise preceded the normalization of the spectra and the measurement of binding energies (BE) was corrected based on the energy of $\mathrm{C} 1 \mathrm{~s}$ at $284.4 \mathrm{eV}$ (Vulcan XC 72R carbon). Quantifications were done from the corresponding XPS peak area after correction with suitable sensitivity factors and the CASA XPS software was used for peak fitting. The electrochemical measurements were conducted in a threeelectrode Pyrex cell using a potentiostat EG\&G PARC Model 362 (Princeton Applied Research). The current densities were normalized with the constant metal loading $(79.3 \mu \mathrm{g}$ 
$\left.\mathrm{cm}^{-2}\right)$ deposited onto a glassy carbon disc $\left(0.071 \mathrm{~cm}^{2}\right.$ geometric surface area). This avoids expressing the activity of the Pt-based catalysts as function of the electrochemical active surface area, dependent of the Pt content, which decreases with the Ni addition. The CO stripping measurement consists of adsorbing during $5 \mathrm{~min} \mathrm{CO}$ at constant potential of $0.1 \mathrm{~V} v s$. RHE until the current decreases down to the capacitive one. Subsequently and at the same applied potential, nitrogen was bubbled in the solution during $25 \mathrm{~min}$ in order to remove remaining free CO. Afterwards, cyclic voltammetry (CV) was performed for recording 2 consecutive cycles: the first one permitted to oxidize adsorbed $\mathrm{CO}$, while the second $\mathrm{CV}$ permits to confirm the complete oxidation of adsorbed CO since the first run. The shift of the main oxidative peak position, known to be at ca. $0.7 \mathrm{~V} v s$. RHE at the Pt surface, allows appreciating how active the $\mathrm{Pt}_{\mathrm{x}} \mathrm{Ni}_{\mathrm{y}}$ catalyst as ensemble effects.

\section{Results and discussion}

The $\mathrm{Pt}_{\mathrm{x}} \mathrm{Ni}_{\mathrm{y}} / \mathrm{C}$ materials were successfully prepared by the BAE method [17]. From our previous paper [17], data from different physicochemical characterizations were summarized in Table 1. $\mathrm{XRD}$ analysis revealed that the increase of $\mathrm{Ni}$ content in $\mathrm{Pt}_{\mathrm{x}} \mathrm{Ni}_{\mathrm{y}} / \mathrm{C}$ materials, leads to the formation of $\mathrm{Ni}(\mathrm{OH})_{2}$ species which presence was observed at 33.5 and $59.3^{\circ} 2 \theta$ values, respectively [17]. Consequently, samples with a high $\mathrm{Ni}$ content $\left(\mathrm{y}_{\mathrm{Ni}}>0.5\right)$ lead to a wide range of particles size ( 2 to $30 \mathrm{~nm}$ ) due to the presence of these species, which are amorphous-like and not well crystallized. Therefore particles and crystallite size were not assessed for pure $\mathrm{Ni} / \mathrm{C}$ to avoid any error of estimation. 
Table 1. Physical properties of $\mathrm{Pt}_{\mathrm{x}} \mathrm{Ni}_{\mathrm{y}}$ materials obtained from TGA/DTA, XRD and TEM measurements

\begin{tabular}{|c|c|c|c|c|c|c|}
\hline \multirow[b]{2}{*}{ Molar ratio } & \multicolumn{5}{|c|}{$\mathrm{Pt}_{\mathrm{x}} \mathrm{Ni}_{\mathrm{y}}$} & \multirow[b]{2}{*}{$0: 1$} \\
\hline & $1: 0$ & $0.7: 0.3$ & $0.5: 0.5$ & 0.3:0.7 & $0.2: 0.8$ & \\
\hline Metal loading (\%) & 20.6 & 19.3 & 22.0 & 23.2 & 22.8 & 21.3 \\
\hline$L v / \mathrm{nm}(\mathrm{XRD})$ & 4.9 & 4.5 & 3.5 & 3.2 & 3.5 & - \\
\hline Dm/nm (TEM) & 2 to 11 & 2 to 9.5 & 1.5 to 7 & 2 to 20 & 3 to 35 & - \\
\hline
\end{tabular}

Further to these results, we scrutinized herein XPS measurements and the correlation with releasing the electrode surface from $\mathrm{CO}$ poisoning.

To provide relevant additional insights on the ensemble effects responsible for the $\mathrm{CO}$-to- $\mathrm{CO}_{2}$ oxidative removal at lower potentials, the material surface state was investigated through XPS analysis (Fig. 1). Therefore, observations are focused on the modifications of the Pt $4 \mathrm{f}$ regions in the different prepared $\mathrm{Pt}_{x} \mathrm{Ni}_{\mathrm{y}}$ materials. As can be seen in Fig. 1a, the $4 \mathrm{f}_{7 / 2}$ and $4 \mathrm{f}_{5 / 2}$ peaks are centered respectively at $71.2 \mathrm{eV}$ and $74.5 \mathrm{eV}$ in $\mathrm{Pt} / \mathrm{C}$, as reported [18]. The decomposition of these peaks suggests that the $\mathrm{Pt}$ material is mainly composed of $\mathrm{Pt}^{0}$ (peaks at 71.1 and $74.5 \mathrm{eV}$ ), but it also contains two $\mathrm{Pt}$ oxide/hydroxide including $\mathrm{Pt}^{2+}$ (peaks at 72.1 and $75.5 \mathrm{eV}$ ) and $\mathrm{Pt}^{4+}$ (peaks at 74.6 and $77.7 \mathrm{eV}$ ). This speciation analysis reveals that the increase of the nickel content enhances the oxide/hydroxide species in the $\mathrm{Pt}_{\mathrm{x}} \mathrm{Ni}_{\mathrm{y}} / \mathrm{C}$ samples, which reaches $c a .25 \%$ (for $\mathrm{Pt}^{2+}$ ) and $22 \%\left(\right.$ for $\mathrm{Pt}^{4+}$ ) (Fig. 1a). Even if the $\mathrm{Pt}_{4} \mathrm{f}_{7 / 2}$ peak is partially in the PtNi-based materials, Fig. 1b shows a slight shift in binding energy which can be associated with an electronic change in the precious element when increasing the nickel content as the ligand effect associated with the nickel amount stops having effect. From the physicochemical characterizations, it can be pointed out that introduction of the Ni element in the Pt structure leads to the formation of nickel hydroxide and Pt oxide/hydroxide species in the prepared $\mathrm{Pt}_{\mathrm{x}} \mathrm{Ni}_{\mathrm{y}} / \mathrm{C}$ catalysts. In addition to this chemical effect, the ligand one was evidenced by XPS 
measurements. Indeed, we are wondering how the ensemble effects match for releasing the electrode surface in the $\mathrm{CO}$-to- $\mathrm{CO}_{2}$ removal at lower electrode potentials.

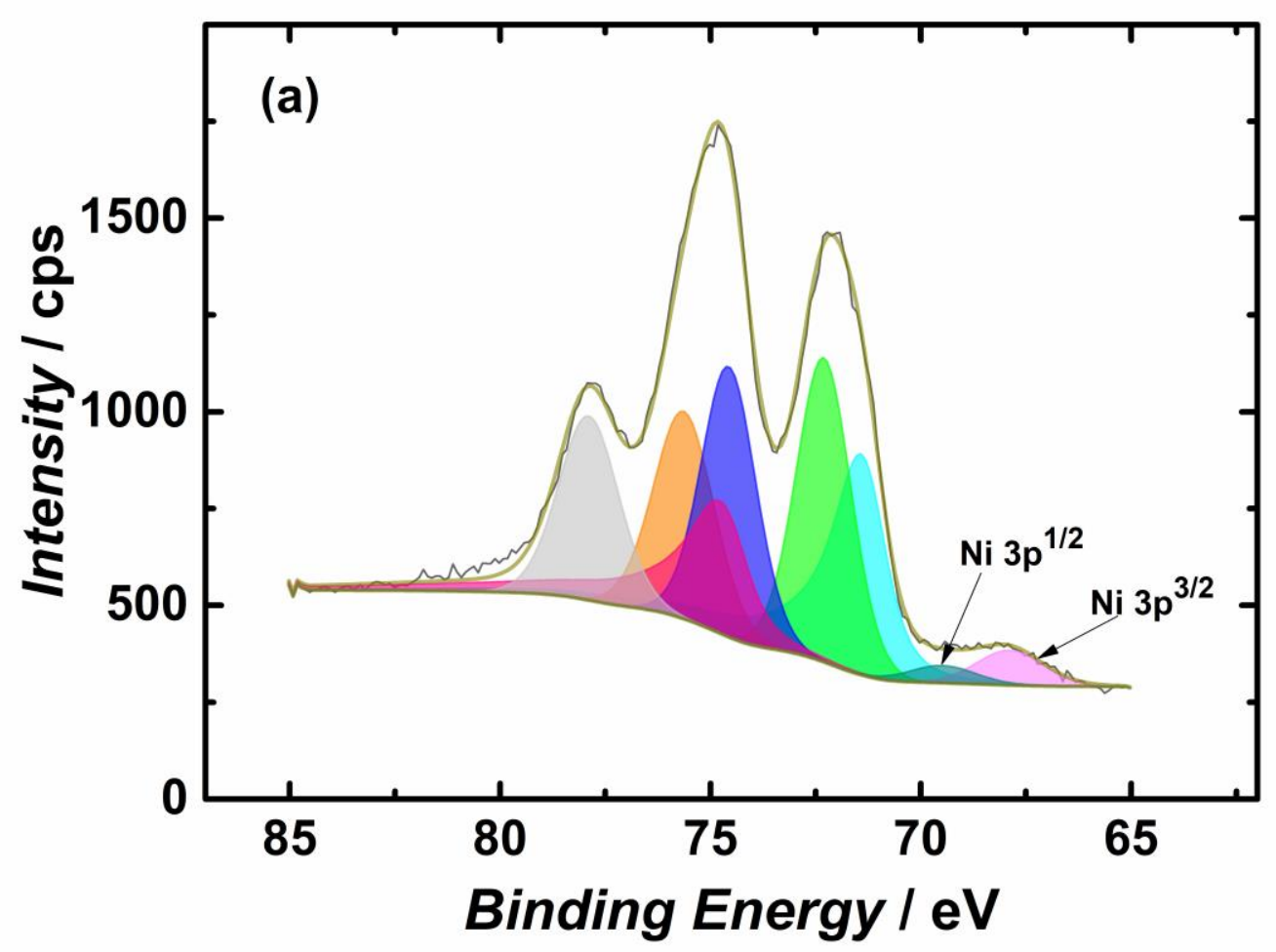




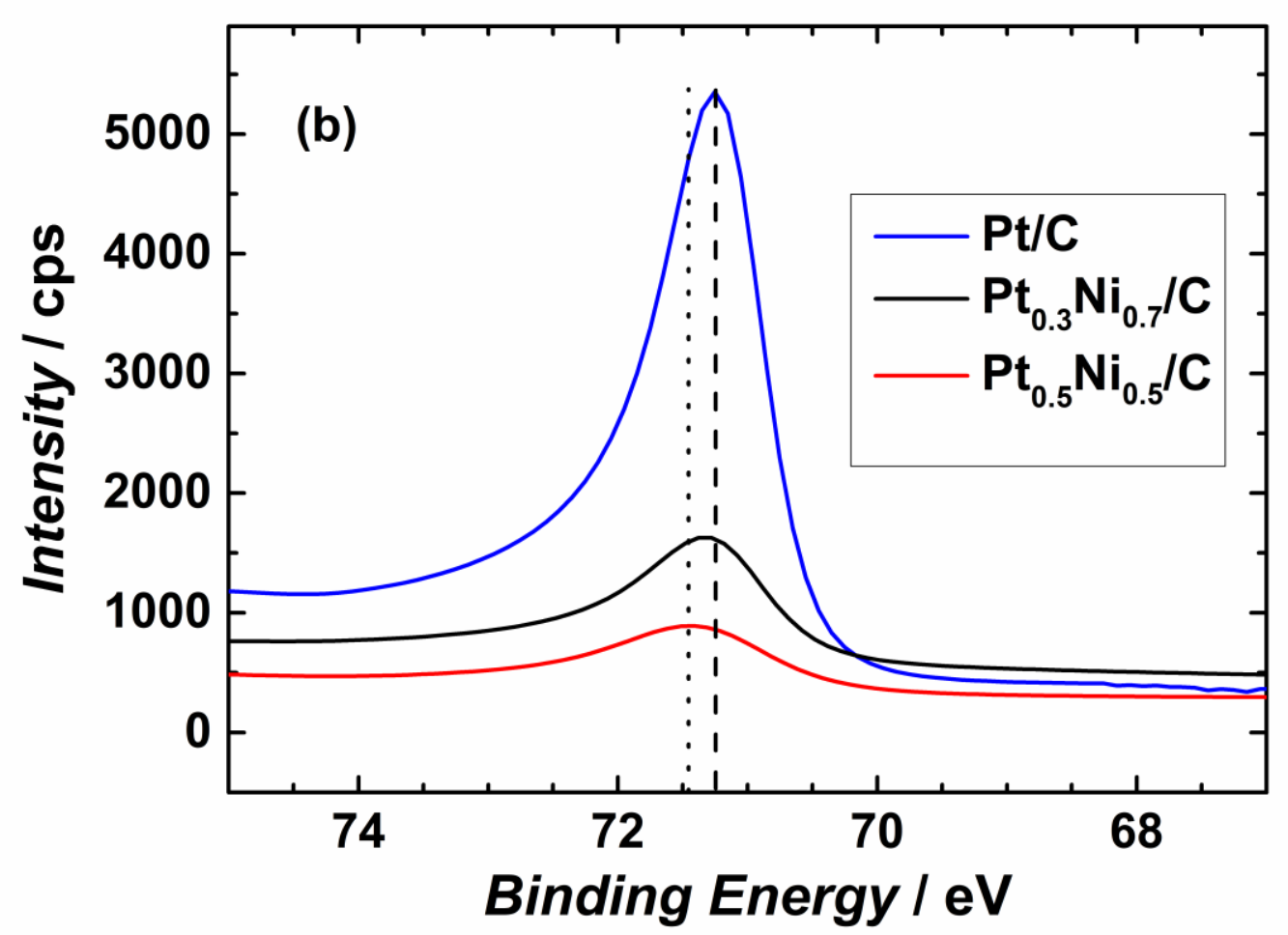

Fig. 1. High resolution XPS spectra of the $\mathrm{Pt}_{\mathrm{x}} \mathrm{Ni}_{\mathrm{y}} / \mathrm{C}$ materials prepared from the BAE method. a) Pt4f and Ni3p in the $\mathrm{Pt}_{0.5} \mathrm{Ni}_{0.5} / \mathrm{C}$ material; b) $\mathrm{Pt}_{4 / 2}$ peak shift of Pt-based materials.

As shown in Fig. 2, the electrochemical characterization of the electrode materials was performed through the $\mathrm{CO}$ stripping technique described above in the experimental section. A voltammogram of a $\mathrm{Pt} / \mathrm{C}$ electrode in the absence and presence of $\mathrm{CO}$ (Fig. 2a) was first recorded to optimize the operating conditions of the electrochemical investigations. Therefore, the three main regions of the signature of a Pt electrode (reversible hydrogen adsorption/desorption, Pt double layer and irreversible Pt hydroxide/oxide) in alkaline medium can be well observed in this voltammogram in the second cycle. It is worthy of noting herein that the upper potential limit was set at the common one in Pt (i.e, we do not consider a higher potential of the $\mathrm{NiOOH}$ formation ( $c a .1 .32 \mathrm{~V}$ vs. RHE), which is convenient for comparing all the as-prepared $\mathrm{Pt}_{\mathrm{x}} \mathrm{Ni}_{\mathrm{y}} / \mathrm{C}$ materials including $\mathrm{Pt} / \mathrm{C}$ with the same upper potential limit). Actually, if $\mathrm{CO}$ is the main intermediate compound which prevents advanced oxidation of carbonaceous 
fuels, the strategy that consists in removing it by bifunctional mechanism deserves to be more investigated. $\mathrm{CO}$-stripping was performed onto $\mathrm{Pt}_{\mathrm{x}} \mathrm{Ni}_{\mathrm{y}} / \mathrm{C}$ catalyst prepared by bromide anion exchange method. One of the various advantages of the surfactant-less BAE method is that no pre-treatment is required before electrochemical experiments $[19,20]$. This means that the electrocatalysts keep for sure the as-prepared aspects and structure at the beginning of the COstripping which is a sensitive electrochemical surface probing technique to evaluate the activity of an electrode. Before each CO-stripping the background cyclic voltammogram (CV) of the catalyst in the supporting electrolyte was recorded. One observes in Fig. 2a a main CO oxidation peak (A) at $0.67 \mathrm{~V}$ vs. RHE. It is commonly assigned to the $\mathrm{CO}$-to- $\mathrm{CO}_{2}$ oxidative removal following the Langmuir-Hinshelwood (L-H) mechanism [21, 22], which proceeds by a concerted desorption of $\mathrm{Pt}-\mathrm{CO}_{\mathrm{ads}}$ and $\mathrm{Pt}-\mathrm{OH}_{\mathrm{ads}}$, the latter adsorbate being the result of the dissociative adsorption of $\mathrm{H}_{2} \mathrm{O}$ molecules (or $\mathrm{HO}^{-}$adsorption in alkaline medium).

$\mathrm{Pt}-\mathrm{CO}_{\mathrm{ads}}+\mathrm{Pt}-\mathrm{OH}_{\mathrm{ads}}+3 \mathrm{HO}^{-} \rightarrow \mathrm{CO}_{3}^{2-}+2 \mathrm{H}_{2} \mathrm{O}+\mathrm{e}^{-}$ Eq. $1(\mathrm{~L}-\mathrm{H})$

Peak $\mathrm{A}$ is preceded by two shoulders (B and C) that are located at 0.58 and $0.40 \mathrm{~V}$ vs. RHE, respectively. It was reported that $\mathrm{CO}$ oxidation at $0.58 \mathrm{~V}$ vs. RHE occurs on terrace sites with (110) orientation, while that at $0.40 \mathrm{~V}$ vs. RHE is taking place on kink-type defects [19, 23]. 

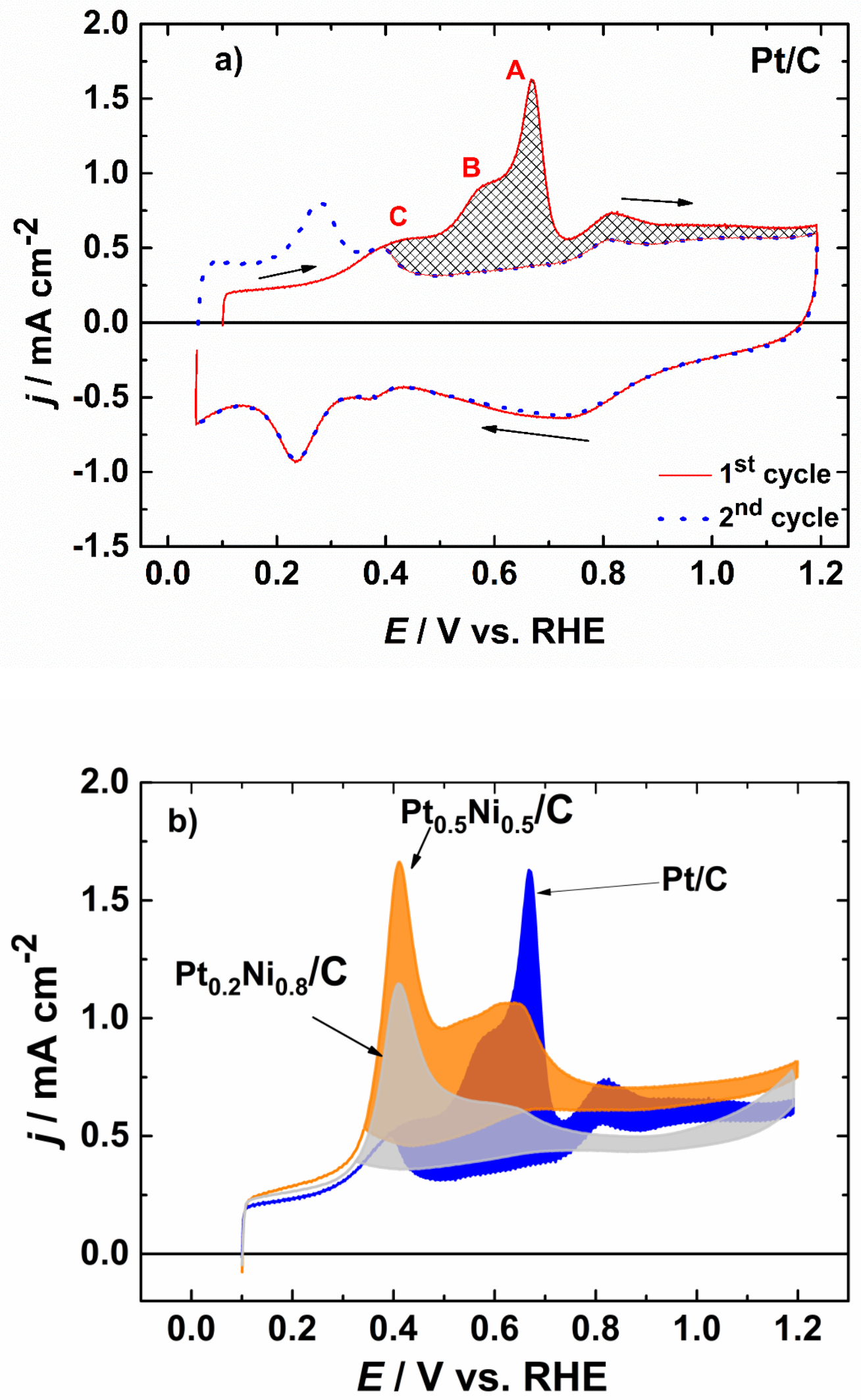
Figure 2. CO-stripping of different molar ratio $\mathrm{Pt}_{\mathrm{x}} \mathrm{Ni}_{\mathrm{y}} / \mathrm{C}$ catalysts in a $\mathrm{CO}$-saturated solution containing $0.1 \mathrm{~mol} \mathrm{~L}^{-1} \mathrm{NaOH}$ recorded at $20 \mathrm{mV} \mathrm{s}^{-1}$ and at $21^{\circ} \mathrm{C}$; a) $1^{\text {st }}$ cycle (red line, presence of $\mathrm{CO}$ ) and second one (blue dot, absence of $\mathrm{CO}$ ) at the Pt electrode surface; b) CO stripping curves on two $\mathrm{Pt}_{\mathrm{x}} \mathrm{Ni}_{\mathrm{y}} / \mathrm{C}$ bimetallics compared with $\mathrm{Pt} / \mathrm{C}$ electrode.

Addition of nickel in the Pt-based material composition increases the peak current at $0.4 \mathrm{~V}$ vs. RHE, synonymous of the electronic transfer of element which downshifts the center of the dband with respect to the Fermi level of Pt $4 \mathrm{f}$ (Figure 1). This enhancement of the activity of the electrode at lower potentials is undoubtedly due to the increasing formation of $\mathrm{Ni}(\mathrm{OH})_{2}$ species up to a molar ratio of $\mathrm{y}_{\mathrm{Ni}}=0.8$ (Figure $2 \mathbf{b}$ ). As at this electrode potential it is considered theoretically that no oxygenated species are present at the Pt surface, the increase in the peak current densities is certainly due to either Eley-Rideal (E-R) mechanism (with the interaction between $\mathrm{HO}^{-}$species from electrolyte and $\mathrm{Pt}-\mathrm{CO}_{\mathrm{ads}}$ ) $[22,24,25]$ or a bifunctional catalysis (BC) mechanism that consists in the interaction between Ni hydroxyl and $\mathrm{Pt}-\mathrm{CO}_{\text {ads }}[26]$, as assumed below:

$\mathrm{Pt}-\mathrm{CO}_{\mathrm{ads}}+\mathrm{Ni}-\mathrm{OH}_{\mathrm{ads}}+3 \mathrm{HO}^{-} \rightarrow \mathrm{CO}_{3}^{2-}+2 \mathrm{H}_{2} \mathrm{O}+\mathrm{e}^{-} \quad$ Eq. 2 (BC)

As result, for $\mathrm{y}_{\mathrm{Ni}}=0.5$ peak $\mathrm{C}$ has a current density value equal to that of peak $\mathrm{A}$ at $\mathrm{Pt} / \mathrm{C}$, i.e an impressive $270 \mathrm{mV}$ shift towards the lower potentials. For $\mathrm{y}_{\mathrm{Ni}}>0.5$, peak $\mathrm{A}$ is disappearing, while peak $\mathrm{C}$ starts decreasing. This double phenomenon can be explained by the conjugation of repulsive adsorption of $\mathrm{CO}$ towards the $\mathrm{HO}$ species and the lowering Pt content, which inhibits the surface structure, i.e prevents the L-H mechanism at the Pt surface. Table 2 gives the coulombic charges associated with the $\mathrm{CO}$ oxidation on the different catalysts. As the $\mathrm{Ni}$ content increases in the bimetallic composition up to $50 \%$, the coulombic charge associated with the $\mathrm{CO}$ oxidation to carbonate increases from 0.69 to $0.79 \mathrm{mC}$. If on $\mathrm{Pt} / \mathrm{C}$ this charge is only associated with the above-mentioned $\mathrm{L}-\mathrm{H}$ mechanism, its increase to $0.79 \mathrm{mC}$ could result 
from the co-existence of the two mechanisms ( $\mathrm{L}-\mathrm{H}$ and $\mathrm{BC})$ on $\mathrm{Pt}_{0.5} \mathrm{Ni}_{0.5} / \mathrm{C}$, as can be seen through the two oxidation peaks at 0.4 and 0.6-0.7 V/RHE (Figure 2b). Then the coulombic charge decreases to $0.54 \mathrm{mC}$ when the $\mathrm{Ni}$ content is higher in the bimetallic anode composition $\left(\mathrm{Pt}_{0.2} \mathrm{Ni}_{0.8} / \mathrm{C}\right)$. This corresponds to the progressive setting up of the $\mathrm{BC}$ and $\mathrm{E}-\mathrm{R}$ mechanisms to that of $\mathrm{L}-\mathrm{H}$ as a result of the marked decrease in the Pt content, which is responsible for and where $\mathrm{CO}$ adsorption phenomena take place.

Table 2. Charge associated with the $\mathrm{CO}$ stripping on different $\mathrm{Pt}_{\mathrm{x}} \mathrm{Ni}_{\mathrm{y}} / \mathrm{C}$ nanocatalysts.

\begin{tabular}{|c|c|}
\hline Nanomaterials & $\begin{array}{c}\text { Charge related to } \mathrm{CO} \\
\text { oxidation peak/ } \mathrm{mC}\end{array}$ \\
\hline $\mathrm{Pt} / \mathrm{C}$ & 0.69 \\
\hline $\mathrm{Pt}_{0.5} \mathrm{Ni}_{0.5} / \mathrm{C}$ & 0.79 \\
\hline $\mathrm{Pt}_{0.2} \mathrm{Ni}_{0.8} / \mathrm{C}$ & 0.54 \\
\hline
\end{tabular}

The excellent catalytic ability of the prepared $\mathrm{Pt}_{x} \mathrm{Ni}_{\mathrm{y}} / \mathrm{C}$ materials towards the $\mathrm{CO}$ oxidation at lower potential values, as the common and major poisoning intermediate in the organics electrooxidation, provides sound evidences to the utilization of this type of catalyst either as CO tolerant cathode or anode in the alcohol fuel cells.

\section{Conclusion}

As $\mathrm{CO}$ is the main poison species that is responsible for the deactivation of the anode catalyst in the direct alcohol fuel cells, its oxidation reaction was investigated on $\mathrm{Pt}_{\mathrm{x}} \mathrm{Ni}_{\mathrm{y}} / \mathrm{C}$ synthesized from a surfactant-less simple reduction approach. XPS measurements revealed to be herein complementary techniques that provided evidences on the ensemble effects allowing to appreciate the excellent ability of $\mathrm{Pt}_{\mathrm{x}} \mathrm{Ni}_{\mathrm{y}} / \mathrm{C}$ anodes towards the $\mathrm{CO}$ oxidation reaction. Indeed, the physicochemical analyses of the materials correlated with the electrochemical characterization allowed to show that the increase of the Ni content in the Pt structure does modify the initial L-H mechanism towards E-R and finally BC ones. The $270 \mathrm{mV}$ negative shift of the CO oxidative removal cannot be explained as the sole effect of the low $\mathrm{Pt} 4 \mathrm{f}_{7 / 2}$ peak shift, 
but also by the contribution of the $\mathrm{Ni}-\mathrm{OH}$ species in the close environment of $\mathrm{Pt}-\mathrm{CO}_{\mathrm{ads}}$, which mainly leads to a bifunctional mechanism. This trend, emphasized by the increase of the $\mathrm{Ni}$ content up to $\mathrm{yNi}_{\mathrm{Ni}}=0.8$, makes these bimetallics, either a $\mathrm{CO}$ tolerant cathode or promising active anode material in a direct alcohol fuel cell. Importantly, this work shows Ni as low-cost and earth-abundant element that allows to decrease the amount of the precious metal in a catalyst composition, not only without decreasing the electroactivity, but with improving its ability towards organics oxidation.

\section{Acknowledgements}

The authors thank the European Union (ERDF) and "Région Nouvelle-Aquitaine for their support.

\section{References}

1. Park S, Tong YY, Wieckowski A, Weaver MJ (2002) Infrared Spectral Comparison of Electrochemical Carbon Monoxide Adlayers Formed by Direct Chemisorption and Methanol Dissociation on Carbon-Supported Platinum Nanoparticles. Langmuir 18 (8):3233-3240. doi:https://doi.org/10.1021/la0113825

2. Park KW, Choi JH, Kwon BK, Lee SA, Sung Y, Ha H-Y, Hong S-A, Kim H, Wieckowski A (2002) Chemical and Electronic Effects of $\mathrm{Ni}$ in $\mathrm{Pt} / \mathrm{Ni}$ and $\mathrm{Pt} / \mathrm{Ru} / \mathrm{Ni}$ Alloy Nanoparticles in Methanol Electrooxidation. Journal of Physical Chemistry B 106 (8):1869-1877. doi:https://doi.org/10.1021/jp013168v

3. Babu PK, Chung JH, Kuk ST, Kobayashi T, Oldfield E, Wieckowski A (2005) Metallic Nature and Surface Diffusion of CO Adsorbed on Ru Nanoparticles in Aqueous Media: A 13C NMR Study. Journal of Physical Chemistry B 109 (7):2474-2477. doi:https://doi.org/10.1021/jp040729k

4. Shao MH, Adzic RR (2005) Electrooxidation of ethanol on a Pt electrode in acid solutions: in situ ATR-SEIRAS study. Electrochimica Acta 50 (12):2415-2422. doi:https://doi.org/10.1016/j.electacta.2004.10.063

5. Arenz M, Stamenkovic V, Blizanac BB, Mayrhofer KJ, Markovic NM, Ross PN (2005) Carbon-supported Pt-Sn electrocatalysts for the anodic oxidation of $\mathrm{H} 2, \mathrm{CO}$, and $\mathrm{H} 2 / \mathrm{CO}$ mixtures.: Part II: The structure-activity relationship. Journal of Catalysis 232 (2):402-410. doi:10.1016/j.jcat.2005.03.022

6. Arenz M, Mayrhofer KJJ, Stamenkovic V, Blizanac BB, Tomoyuki T, Ross PN, Markovic NM (2005) The Effect of the Particle Size on the Kinetics of CO Electrooxidation on High 
Surface Area Pt Catalysts. Journal of American Chemical Society 127 (18):6819-6829. doi:10.1021/ja043602h

7. Colmati F, Antolini E, Gonzalez ER (2005) Pt-Sn/C electrocatalysts for methanol oxidation synthesized by reduction with formic acid. Electrochimica Acta 50 (28):5496-5503. doi:http://dx.doi.org/10.1016/j.electacta.2005.03.030

8. Chen Z, Qiu X, Lu B, Zhang S, Zhu W, Chen L (2005) Synthesis of hydrous ruthenium oxide supported platinum catalysts for direct methanol fuel cells. Electrochemistry Communications 7 (6):593-596. doi:https://doi.org/10.1016/j.elecom.2005.04.002

9. Colmati F, Antolini E, Gonalez ER (2007) Ethanol Oxidation on Carbon Supported Pt-Sn Electrocatalysts Prepared by Reduction with Formic Acid. Journal of the Electrochemical Society 154 (1):B39-B47. doi:https://doi.org/10.1149/1.2382349

10. Song S, Tsiakaras P (2006) Recent progress in direct ethanol proton exchange membrane fuel cells (DE-PEMFCs). Applied Catalysis B: Environmental 63 (3-4):187-193. doi:https://doi.org/10.1016/j.apcatb.2005.09.018

11. Simões FC, dos Anjos DM, Vigier F, Léger JM, Hahn F, Coutanceau C, Gonzalez ER, Tremiliosi-Filho G, de Andrade AR, Olivi P, Kokoh KB (2007) Electroactivity of tin modified platinum electrodes for ethanol electrooxidation. Journal of Power Sources 167 (1):1-10. doi:http://dx.doi.org/10.1016/j.jpowsour.2006.12.113

12. Chen C-C, Lin C-L, Chen L-C (2015) A binary palladium-bismuth nanocatalyst with high activity and stability for alkaline glucose electrooxidation. Journal of Power Sources 287:323-333. doi:http://dx.doi.org/10.1016/j.jpowsour.2015.04.083

13. Holade Y, Servat K, Napporn TW, Morais C, Berjeaud J-M, Kokoh KB (2016) Highly Selective Oxidation of Carbohydrates in an Efficient Electrochemical Energy Converter: Cogenerating Organic Electrosynthesis. ChemSusChem 9 (3):252-263. doi:10.1002/cssc.201501593

14. Strmcnik DS, Tripkovic DV, van der Vliet D, Chang K-C, Komanicky V, You H, Karapetrov G, Greeley JP, Stamenkovic VR, Marković NM (2008) Unique Activity of Platinum Adislands in the CO Electrooxidation Reaction. Journal of American Chemical Society 130 (46):15332-15339. doi:10.1021/ja8032185

15. Rudi S, Teschner D, Beermann V, Hetaba W, Gan L, Cui C, Gliech M, Schlögl R, Strasser P (2017) pH-Induced versus Oxygen-Induced Surface Enrichment and Segregation Effects in Pt-Ni Alloy Nanoparticle Fuel Cell Catalysts. ACS Catalysis 7 (9):6376-6384. doi:10.1021/acscatal.7b00996

16. Holade Y, Servat K, Rousseau J, Canaff C, Poulin S, Napporn TW, Kokoh KB (2015) Electrochemical and Physicochemical Characterizations of Gold-Based Nanomaterials: Correlation between Surface Composition and Electrocatalytic Activity. Journal of the Electrochemical Society 162 (14):H929-H937. doi:10.1149/2.0601514jes

17. Dessources S, Morais C, Napporn TW, Kokoh KB (2016) Reversible Electrocatalytic Activity of Carbon-Supported $\mathrm{Pt}_{\mathrm{x}} \mathrm{Ni}_{1-\mathrm{x}}$ in Hydrogen Reactions. ChemPhysChem 17 (23):3964-3973. doi:10.1002/cphc.201600733

18. Corcoran CJ, Tavassol H, Rigsby MA, Bagus PS, Wieckowski A (2010) Application of XPS to study electrocatalysts for fuel cells. Journal of Power Sources 195 (24):7856-7879. doi:http://dx.doi.org/10.1016/j.jpowsour.2010.06.018 
19. Lai SCS, Lebedeva NP, Housmans THM, Koper MTM (2007) Mechanisms of Carbon Monoxide and Methanol Oxidation at Single-crystal Electrodes. Topics in Catalysis 46 (34):320-333. doi:10.1007/s11244-007-9010-y

20. Bergelin M, Herrero E, Feliu JM, Wasberg M (1999) Oxidation of CO adlayers on Pt(111) at low potentials: an impinging jet study in $\mathrm{H}_{2} \mathrm{SO}_{4}$ electrolyte with mathematical modeling of the current transients. Journal of Electroanalytical Chemistry 467 (1-2):74-84. doi:http://dx.doi.org/10.1016/S0022-0728(99)00046-7

21. Maillard F, Savinova ER, Stimming U (2007) CO monolayer oxidation on Pt nanoparticles: Further insights into the particle size effects. Journal of Electroanalytical Chemistry 599 (2):221-232. doi:doi: 10.1016/j.jelechem.2006.02.024

22. Spendelow JS, Goodpaster JD, Kenis PJA, Wieckowski A (2006) Mechanism of CO Oxidation on Pt(111) in Alkaline Media. Journal of Physical Chemistry B 110 (19):95459555. doi:https://doi.org/10.1021/jp060100c

23. Farias MJS, Vidal-Iglesias FJ, Solla-Gullón J, Herrero E, Feliu JM (2014) On the behavior of CO oxidation on shape-controlled Pt nanoparticles in alkaline medium. Journal of $\begin{array}{llll}\text { Electroanalytical Chemistry } & 716 & (0): 16-22 .\end{array}$ doi:http://dx.doi.org/10.1016/j.jelechem.2013.07.017

24. Mukherjee AK, Sinha I (2009) Effect of the Eley-Rideal step on catalytic oxidation of CO under periodic external pressure. Applied Surface Science 255 (12):6168-6172. doi:https://doi.org/10.1016/j.apsusc.2009.01.073

25. Urchaga P, Baranton S, Coutanceau C, Jerkiewicz G (2012) Evidence of an Eley-Rideal Mechanism in the Stripping of a Saturation Layer of Chemisorbed CO on Platinum Nanoparticles. Langmuir 28 (36):13094-13104. doi:10.1021/la302388p

26. Roca-Ayats M, Guillén-Villafuerte O, García G, Soler-Vicedo M, Pastor E, MartínezHuerta MV (2018) PtSn nanoparticles supported on titanium carbonitride for the ethanol oxidation reaction. Applied Catalysis B: Environmental 237:382-391. doi:10.1016/j.apcatb.2018.05.078 
Graphical Abstract

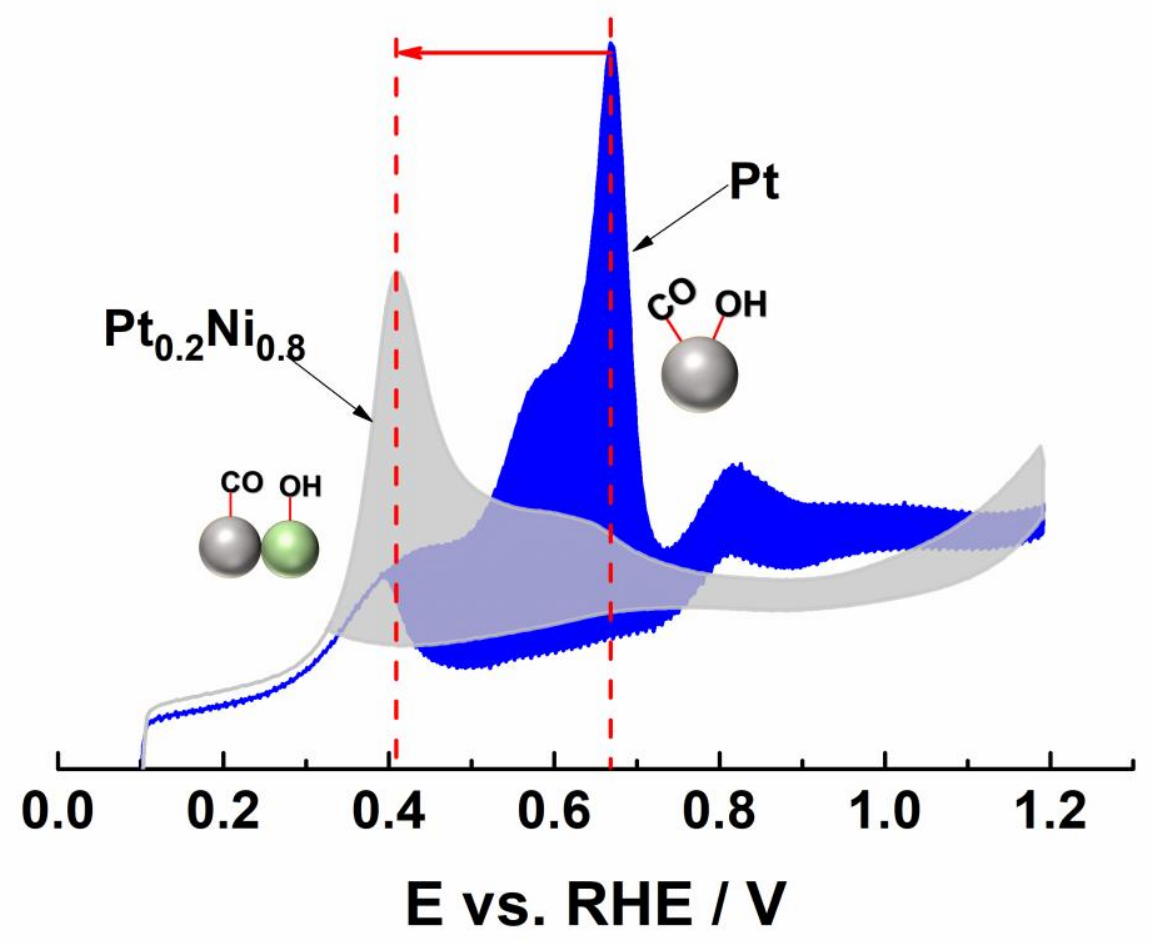

